\title{
Análisis de la (in)eficacia del principio de obligatoriedad en el ejercicio de la acción penal en la etapa intermedia del proceso penal chileno*
}

\author{
Manuel Rodríguez Vega**
}

\begin{abstract}
RESUMEN
En este artículo se constata que la regulación nacional no contempla, respecto de la etapa intermedia del procedimiento penal ordinario, adecuados controles procesales acerca del obligatorio ejercicio de la acción penal según la legalidad sustantiva que debe impulsar el Ministerio Público por imperativo legal, lo que deja como resultado múltiples, extendidos e importantes espacios para el abandono o degradación de su ejercicio de manera discrecional, invirtiéndose con ello el modelo original de la codificación procesal, al desplazar, en el campo forense, la discrecionalidad a la obligatoriedad como regla en la persecución criminal.
\end{abstract}

Discrecionalidad - principio de obligatoriedad - conclusión investigación sobreseimiento - decisión de no perseverar

\section{Analysis of the (lack of) effectiveness of the idea of mandatory criminal action in the Chilean criminal proceedings}

\begin{abstract}
This article notes that Chilean regulation does not provide, for the intermediate stage of ordinary criminal proceedings, an appropriate procedural control on the legally compulsory exercise of criminal prosecution. This lead to an state of affairs in which there are multiple and important opportunities in which, exercising the prosecutor discretion, the prosecution may be abandoned, thus reversing the original decision of the model that moved from a discretionary to a mandatory rule.
\end{abstract}

Discretionary prosecution - compulsory prosecution - end of criminal investigation provisional closure - abandon of the prosecution

\footnotetext{
* Por su muy valiosa colaboración editorial, el autor agradece a Constanza Godoy Aguilar, ayudante ad honorem de la Escuela de Derecho de la Universidad Católica Silva Henríquez.

** Doctor en derecho, Universidad de Chile (2014); Magíster en Derecho, Universidad de Talca (2008); Licenciado en ciencias jurídicas y sociales, P. Universidad Católica de Chile (2001); profesor de la Escuela de Derecho, Universidad Católica Silva Henríquez; correo electrónico: mrodriguez@ucsh.cl.

Artículo recibido el 26 de abril de 2014 y aceptado para su publicación el 27 de marzo de 2015.
} 


\section{INTRODUCCIÓN}

Como nos enseña Maier, el principio de legalidad, desde un punto de vista negativo, significa que ningún criterio de oportunidad -político-utilitario, por conveniencia práctica, económica, temporal, etc.- autoriza, en principio, a prescindir de la persecución penal frente a la noticia de la comisión de un hecho punible ${ }^{1}$. A este principio, por su mayor precisión conceptual y neutralidad terminológica, nos referirnos como obligatoriedad de la acción penal ${ }^{2}$, sin desconocer que parte importante de la doctrina europeo-continental y nacional, suele denominarlo indistintamente como principio de legalidad o de legalidad procesal. Por similares motivos, también optamos en general por hablar de discrecionalidad para aludir al principio antagónico al de obligatoriedad de la acción penal, en desmedro del término oportunidad, pese a que esta denominación ha adquirido carta de naturaleza en nuestro medio jurídico ${ }^{3}$.

En el sistema de justicia penal chileno este principio se consagra en el artículo 166 , inc. $2^{\circ}$, del Código Procesal Penal (en adelante, CPP), al disponer que "cuando el ministerio público tomare conocimiento de la existencia de un hecho que revistiere caracteres de delito, con el auxilio de la policía, promoverá la persecución penal, sin que pueda suspender, interrumpir o hacer cesar su curso, salvo en los casos previstos en la ley" ${ }^{4}$, de ese modo, la investigación se iniciará ya sea por denuncia, por querella

${ }^{1}$ Maier, J., Derecho Procesal Penal Argentino, Hammurabi, Buenos Aires, 1989, T. I, vol. b, 548 p. Roxin, C., Derecho Procesal Penal, Trad. G. Córdoba y D. Pastor, Editores del Puerto, Buenos Aires, 2000, p. 89, por su parte, lo define como el deber de realizar las investigaciones cuando existe la sospecha de que se ha cometido un hecho punible y, por otra parte, de formular la acusación cuando después de las investigaciones sigue existiendo esa sospecha vehemente, mientras Montero, J., Gómez, J., Montón, A., y Barona, S., Derecho Jurisdiccional III. Proceso Penal, Bosch, Barcelona, 2013, p. 29, estima que una vez iniciado el proceso penal, este ha de tender a llegar a su fin normal de la sentencia, no pudiendo acabarse por actos discrecionales de nadie, sin que el proceso penal pueda ser revocado, suspendido, modificado o suprimido, sino en los casos en que así lo permita una expresa disposición de la ley, lo que no puede dejarse a la discrecionalidad de persona alguna, sin que ello suponga que el proceso tenga que acabar siempre con sentencia, sino solo que en su desarrollo y terminación debe aplicarse la legalidad estricta.

2 Siguiendo con ello a Díez-Picazo, L.M., El poder de acusar, Ministerio Fiscal y Constitucionalismo, Ariel, Barcelona, 2000, p. 13. v.t. Conde-Pumpido, C., "El principio de oportunidad reglada: su posible incorporación al sistema del proceso penal español”, en AA.VV. La reforma del Proceso Penal. II Congreso de Derecho Procesal de Castilla y León, Ministerio de Justicia, Madrid, 1989, pp. 287-308.

${ }^{3}$ De la Oliva, A., Derecho Procesal Penal 4a Edición, Centro de Estudios Areces, Madrid, 1999, pp. 20-21, reseña que "con frecuencia se entiende el principio de oportunidad con gran amplitud y vaguedad. Así entendido, engloba y significa tantas y tan diversas cosas, que, en realidad, no significa nada claro y seguro". Acostumbra, por ejemplo, engarzarse el estudio del principio de oportunidad a la delincuencia bagatelaria o de nimiedad (minima no curat praetor) -ámbito en el que no se agota nuestra investigación-, por todos, Armenta, T., Criminalidad de bagatela y Principio de Oportunidad. Alemania y España, Promociones y Publicaciones Universitarias, Barcelona, 1991, p. 23; Otero, M., "El principio de oportunidad y salidas alternativas", en Revista de Derecho Procesal , No 20, 2005, pp. 295-336; Trillo, J., El fiscal en el nuevo proceso penal, Comares, Granada, 2008, pp. 201 y 220; y Maturana, C., y Montero, R., Derecho Procesal Penal, Legal Publishing, Santiago, 2010, T. I, p. 575.

${ }^{4}$ Para Bettiol, G., Instituciones de Derecho Penal y Procesal, trad. F. Gutiérrez-Alviz y Conradi, Bosch, Barcelona, 1977, pp. 198 y 200, en cambio, la obligación de aplicar la pena deriva directamente de cada 
o de oficio (Art. 172 del CPP) ${ }^{5}$. Esta promoción de la persecución mediante las indagaciones preliminares está sometida a las exigencias de racionalidad y justicia propias del procedimiento judicial, conforme se determinó por el constituyente con la reforma al artículo $19 \mathrm{~N}^{\circ} 3$ inc. $5^{\circ}$ (actual inc. $6^{\circ}$ ) de la Constitución Política de la República (en adelante, CPR) -mediante Ley 19.519 de 16 de septiembre de 1997-, la que buscó sujetar las pesquisas de la Fiscalía también, y expresamente, a las exigencias que la Carta Fundamental impone al procedimiento jurisdiccional ${ }^{6}$.

Aun cuando la máxima de obligatoriedad de la acción penal no supone que toda investigación deba culminar en una acusación, sino solo la obligación del Ministerio Público (en adelante, MP) de promover la persecución sobre toda notitia criminis que llegue a su conocimiento, aunque sea para pedir después el sobreseimiento, no perseverar en la investigación o alcanzar una salida alternativa ${ }^{7}$, sería un craso error estimar que

norma de carácter sustancial. En cuanto a la residencia constitucional o legal del principio de obligatoriedad en España, v. Montero, J., Ortells, M., y Gómez, J., Derecho Jurisdiccional. Parte General I, Bosch, Barcelona, 1989, $2^{a}$ ed., pp. 497-498; Aguilera, E., El principio de consenso: La conformidad en el proceso penal español, Cedecs, Barcelona, 1998, 1ª ed., p. 143; Prada, J., "España”, en Maciá, R., Sistemas de Proceso Penal en Europa, Cedecs, Barcelona, 1998, pp. 99 n. 23; De la Oliva, A., Derecho Procesal Penal, Centro de Estudios Areces, Madrid, 1999, $4^{\mathrm{a}}$ ed., pp. 22, 24-25.

${ }^{5}$ Acerca de las formas de inicio de la investigación, v. Valdés, R., "Libro II del Nuevo Código Procesal Penal”, en AAVV, Apuntes de Derecho Procesal Penal. El Ministerio Público y el Proceso Penal Oral, LegalPublishing, Santiago, 2010, 8 ed., pp. 171 y ss; Medina, R., Morales, L., y Dorn, C., Manual de Derecho Procesal Penal, LexisNexis, Santiago, 2007, $2^{\text {a }}$ ed., pp. 225 y ss; y, Aguilar, C., Manual de Derecho Procesal Penal Oral, Metropolitana, Santiago, 2004, T. I, pp. 281 y ss.

${ }^{6}$ Segundo Informe de la Comisión de Constitución, Legislación, Justicia y Reglamento del Senado de Chile (en adelante, Comisión del Senado). Según se dejó constancia en el mismo documento, la indicación también se justificó, porque debido a que la Constitución no fija más límites o parámetros para lo que debe entenderse por un debido proceso que la justicia y la racionalidad, vale la pena hacer el mismo encargo al legislador en el caso de la investigación de delitos que dirigirá el MP; como explica Aguilar, C., Manual de Derecho Procesal Penal Oral, Metropolitana, Santiago, 2004, T. I, p. 11, la racionalidad y justicia de la investigación es un requisito de la legalidad del juzgamiento; Piedrabuena, G., Introducción a la Reforma Procesal Penal, Fallos del Mes, Santiago, 2000, p. 64, añade que si una ley da facultades amplias al Fiscal y este las ejerce en forma contraria a la razón y a la justicia y si al hacerlo conculca alguna de las garantías constitucionales, la jurisdicción ordinaria tiene facultad para restablecer el imperio del derecho, sea mediante los recursos de protección o de amparo u otra vía jurisdiccional; v.t. Medina, R., Morales, L., y Dorn, C., Manual de Derecho Procesal Penal, LexisNexis, Santiago, 2007, $2^{\mathrm{a}}$ ed., p. 244, quienes, pese a la exclusividad y discrecionalidad de la investigación dirigida por el MP, niegan que pueda ejercerse de manera arbitraria. Nuestra Corte Suprema, en SCS, Rol No 2.693-2005, de 3.8.2005 por su parte, ha señalado que la investigación que inicie el Fiscal después de haber tomado conocimiento de un hecho ilícito, debe informarse "por criterios de transparencia, objetividad y profesionalismo".

${ }^{7}$ En términos similares, mutatis mutandi, v Claría, J., Derecho Procesal Penal, Rubinzai-Culzoni, Buenos Aires, T. I, p. 161; Ruiz, E., Estudios de Derecho Procesal Penal, Comares, Granada, 1995, p. 102; Ferrajoli, L., Derecho y Razón. Teoria del Garantismo Penal, Trotta, Madrid, 2001, 5a ed., p. 570; Duce, M., y Riego, C., Proceso Penal. Editorial Jurídica, Santiago, 2009, p. 170, n. 2; y Burgos, J., Modelo y Propuestas para el Proceso Penal Español, ePraxis, Sevilla, 2012, p. 60, para quien el ejercicio de la acción penal mediante querella no es un derecho incondicionado, sino que es compatible con un pronunciamiento motivado del órgano judicial en la fase instructora que le ponga término anticipadamente. Como contrapartida, y según explica Weigend, T., "Prosecution: Comparative Aspects", en AAVV, Encyclopedia of Crime E Justice, vol. 3, 2a ed., Macmillan Reference USA, New York, 2003, p. 1237, el Fiscal ejerce discreción, en su sentido propio, solo cuando 
el principio en estudio se satisface con el mero inicio y desarrollo de la investigación, resultando más o menos indiferente un discrecional aborto posterior del procedimiento. Muy por el contrario, al deber del MP de investigar impuesto por el principio de obligatoriedad, le sigue el de acusar si los antecedentes reunidos en la investigación lo justifican ${ }^{8}$. Y tal justificación para acusar y realizar el juicio oral existirá solo cuando razonablemente se haya llegado a la constatación, no de que va a obtenerse una sentencia condenatoria, pero sí de que existen indicios suficientes de que el hecho es delictivo y que de él es autor el imputado?.

Así, una vez concluida la investigación, el Fiscal declarará cerrada esta etapa del proceso y podrá, dentro de los 10 días siguientes, solicitar el sobreseimiento definitivo o temporal de la causa; formular acusación, cuando estimare que la investigación proporciona fundamento serio para el enjuiciamiento del imputado contra quien se hubiere formalizado la misma; o, comunicar su decisión de no perseverar en el procedimiento, por no haberse reunido durante la investigación los antecedentes suficientes para fundar una acusación (Art. 248 del CPP). La decisión que adopte el MP de acuerdo con lo que cree acorde al resultado de la instrucción -acusar, solicitar sobreseimiento o no perseverar en el procedimiento-, como reconoce nuestro máximo tribunal, debe ceñirse en todo caso a las exigencias del régimen positivo vigente ${ }^{10}$, es decir, al principio de legalidad tanto en su dimensión sustantiva como procesal.

Nos abocaremos enseguida al examen de las posibilidades judiciales de control sobre el discrecional no ejercicio de la acción penal por el MP mediante estas determinaciones, comenzando antes con la revisión de las potestades del tribunal frente al cierre de una investigación incompleta.

considera la condena del sospechoso como probable y aun así no presenta cargos, no refiriéndose entonces la discreción a la suficiencia de evidencia sino a consideraciones de política.

${ }^{8}$ Roxin, C., Derecho Procesal Penal, Trad. G. Córdoba y D. Pastor, Editores del Puerto, Buenos Aires, 2000, p. 89; De la Oliva, A., Derecho Procesal Penal, Centro de Estudios Areces, Madrid, 1999, $4^{a}$ ed., p. 191, explica que la acción comprende tanto el poder de provocar el inicio del proceso como "el de que se mantenga vivo a fin de ser y actuar como parte acusadora”; en tanto, Burgos, J., Modelo y Propuestas para el Proceso Penal Español, ePraxis, Sevilla, 2012, p. 69, refiere -teniendo presente que en la mayoría de los procedimientos penales de España es el juez instructor quien dirige la investigación- que la búsqueda de la verdad material es obligación de todos los órganos del Estado que participan en la investigación penal, aunque el objetivo del Ministerio Público no es la sentencia sino la acusación; del juego de los $§ 152.2$ y 170.1 StPO, Gómez, J-L., El Proceso Penal Alemán, Introducción y Normas Básicas, Bosch, Barcelona, 1985, p. 47, afirma que conforme al principio de legalidad, "de un lado, la Fiscalía debe practicar las investigaciones en caso de que existan sospechas de haberse cometido un hecho delictivo; de otro, está obligado a formular la acusación en caso de que permanezcan, tras esas investigaciones, suficientes sospechas acerca de ese hecho”.

9 Montero, J., Gómez, J, Montón, A., y Barona, S., Derecho Jurisdiccional III. Proceso Penal, Bosch, Barcelona, 2013, p. 31. Creemos que solo de esta forma es posible aspirar a un estándar objetivo como rasero de esta actuación procesal, de lo contrario, siempre podrá invocarse la posibilidad de que el particular criterio de algunos jueces integrantes -aun cuando la integración generalmente sea imposible de prever al momento de acusar-, defina de antemano una decisión jurisdiccional desfavorable para el MP. De esa manera, bajo la excusa de un pseudorrealismo jurídico, se ampararía pura discrecionalidad.

${ }^{10}$ SCS, Rol No 2.693-2005, de 03.08.2005. 


\section{CONTROL JURISDICCIONAL SOBRE UNA INVESTIGACIÓN CERRADA E INCOMPLETA}

Nuestra jurisprudencia constitucional en sentencia Rol No 1341-2009, de 15 de abril de 2010 (cons. 49 ), y Rol N ${ }^{\circ}$ 1394-2009, de 13 de julio de 2010 (cons. 21 ${ }^{\circ}$ ), ha dictaminado que "para que proceda el ejercicio de la facultad de no perseverar, es imprescindible que el fiscal haya practicado todas 'las diligencias necesarias para la averiguación del hecho punible y sus autores, cómplices o encubridores'. Esta es una expresión de la obligación del Ministerio Público de investigar, establecida en el artículo 183 del Código Procesal Penal en relación con el artículo 257 del mismo Código" ${ }^{11}$.

Si la Fiscalía no ha respondido adecuadamente frente a la labor indagatoria que le impone el artículo 248 ya aludido, esto es, haber practicado "las diligencias necesarias para la averiguación del hecho punible y sus autores, cómplices o encubridores”, con el objeto de posibilitar la acusación fundada del imputado, una vez más, al igual que a lo largo de todo el proceso, el legislador descansa en el celo de la víctima para promover la perfección de la investigación, sujeto procesal que podrá solicitar al tribunal su reapertura y la reiteración de las actuaciones oportunamente demandadas al MP, y que este hubiere rechazado o respecto de las cuales no se hubiere pronunciado (Art. 257 del CPP). Apuntemos que el Proyecto de CPP ni siquiera contemplaba esta herramienta, la que fue incorporada en el primer informe de la Comisión de la Cámara de Diputados, como "ampliación de la investigación" (Art. 327), autorizándose al juez a disponer directamente la práctica de las diligencias a la policía, punto este último que fue modificado en el Senado a raíz de una indicación parlamentaria, según se dejó constancia en el segundo informe de la Comisión del Senado. Este precepto volvió a mudar posteriormente mediante la Ley 20.074, en cuanto a la oportunidad para solicitar la reapertura y

${ }^{11}$ En sintonía, la SCS, Rol No 4.978-2011, de 02.09.2011, declaró que: "si bien el Ministerio Público tiene como prerrogativa exclusiva, dirigir la investigación de los hechos constitutivos de delito, tal como lo consignan los artículos 83 de la Constitución Política, $3^{\circ}$ del Código Procesal Penal y $1^{\circ}$ de la Ley 19.640, dicho cometido debe llevarse a cabo en la forma prevista por la Constitución y las leyes, lo que supone actuar de acuerdo con criterios de objetividad, profesionalismo e idoneidad técnica, que den cuenta del cumplimiento cabal e íntegro de la función exclusiva que la sociedad le ha conferido, siendo destacable al efecto lo dispuesto en el artículo 180 del Código del ramo, en cuanto impone al fiscal, frente al conocimiento de hechos que puedan configurar un delito de acción penal pública -como ocurre en la especie-, proceder a la práctica de todas aquellas diligencias pertinentes y útiles al esclarecimiento y averiguación del mismo, de las circunstancias relevantes para la aplicación de la ley penal, de los partícipes del hecho y de las circunstancias que sirvieren para verificar su responsabilidad. De este modo, esta atribución propia del ente persecutor oficial no puede ser ejercida de manera deficiente ni arbitraria, sino que al contrario, resulta imperativo que se lleve a cabo en forma objetiva y completa, en términos que permita indagar efectivamente si existen hechos constitutivos de delito que ameriten ser perseguidos penalmente, pues no es posible aceptar que por razones estratégicas o de simple ineficiencia puedan omitirse hechos o pruebas relevantes, sea para la averiguación del hecho punible y sus responsables, o bien, para descartar otras hipótesis viables y plausibles, invocadas por alguno de los demás intervinientes del proceso penal”, v.t. SCA de Arica, Rol No 137-2012, de 4.6.2012, y SCA de Sn. Miguel, Rol No 739-2012, de 19.6.2012. 
ampliando su procedencia también respecto de diligencias pedidas acerca de las cuales el MP no se hubiere pronunciado.

Si el Juzgado de Garantía (en adelante, JG, también para Juez de Garantía) acogiere la solicitud, ordenará al Fiscal reabrir la investigación y proceder al cumplimiento de las diligencias, en el plazo que le fijará ${ }^{12}$. Esta facultad judicial ha sido criticada por Tavolari, tachándola de inconstitucional por vulnerar la exclusividad de la dirección de la investigación otorgada al MP, mientras Cerda y Hermosilla ${ }^{13}$ expresan que se trata de una facultad "que altera el principio acusatorio en cuanto a la separación de las funciones de investigar y decidir" 14 . Respecto de esta última opinión, creemos que da un alcance equivocado al principio acusatorio, el que impone solamente el cumplimiento de tres exigencias básicas, todas referidas a la introducción y fijación del objeto del proceso: a) no puede atribuirse al juzgador poderes de dirección material del proceso que cuestionen su imparcialidad; b) no puede haber juicio oral (o condena) si no hay acusación formulada por persona ajena al tribunal sentenciador; y, c) no puede dictarse sentencia por hechos distintos de los incluidos en la acusación ni respecto de persona distinta de la acusada. ${ }^{15}$ Por tanto, fundamentalmente el principio acusatorio realiza una distribución

12 De no cumplirse por el MP las diligencias al vencimiento del plazo fijado por el JG, la SCA de Rancagua, Rol No 322-2012, 31.01.2013, ha declarado que el JG no debe aceptar el cierre de la investigación, ya que de lo contrario "le bastaría al persecutor dejar pasar el plazo que se haya fijado, sin realizar diligencia alguna, para burlar la orden del juez y su propio deber, hipótesis que resulta inaceptable. El plazo que la ley dice que el juez ha de señalar, no es extintivo, como supuso ante estrados la defensa; no hace desaparecer la obligación del ente persecutor, como es evidente. Es un plazo que tiene por preciso objeto obligarle a actuar diligentemente, y que, una vez extinguido, permite a quien haya obtenido la reapertura, reclamar el efectivo cumplimiento, si no se ha completado la obligación, sin perjuicio de las responsabilidades que pueda, además, acarrear para el fiscal renuente”.

13 Cerda, R., y Hermosilla, F., El Código Procesal Penal. Comentarios, Concordancia y Jurisprudencia, Librotecnia, Santiago, 2006, $2^{\circ}$ ed., p. 312.

${ }^{14}$ Tavolari, R., "De la prueba. Sistema probatorio. Medios de prueba. Valor probatorio", en AAVV, El Nuevo Proceso Penal Chileno, Universidad de Concepción, Facultad de Ciencias Jurídicas y Sociales, dpto. de Derecho Procesal, 2000, p. 151. En sintonía, Cerda, R., y Hermosilla, F,. El Código Procesal Penal. Comentarios,

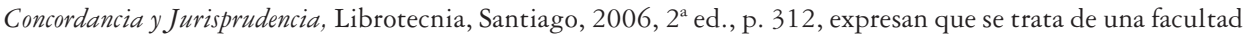
"que altera el principio acusatorio en cuanto a la separación de las funciones de investigar y decidir".

${ }^{15}$ Del Río, C., Los poderes de decisión del juez penal. Principio acusatorio y determinadas garantías procesales (el deber de correlación), Editorial Jurídica, Santiago, 2009, pp. 77-78. Armenta, T., Lecciones de Derecho Procesal Penal $5^{a}$ edición, Marcial Pons, Madrid, 2010, p. 42, por su lado, resume el principio acusatorio en una idea simple pero importante: "no hay proceso sin acusación", que a su vez comprende otra idea: "quien acusa no puede juzgar”. En ese orden, los elementos esenciales del principio acusatorio serían dos: la necesidad de una acción previa para iniciar y continuar el proceso, y la exigencia de una separación estricta entre los órganos que ostentan la función acusadora y la enjuiciadora. Armenta, T., Criminalidad de bagatela y principio de oportunidad: Alemania y España, Promociones y Publicaciones Universitarias, Barcelona,1991, p. 33; y Armenta, T., Algunas reflexiones en torno a la convergencia entre los procesos civil y penal y la deriva común hacia métodos extrajurisdiccionales, Marcial Pons, Madrid, 2013, p. 229, aclarando que dichas exigencias no comportan, sin embargo, que la contradicción y mucho menos la igualdad impere a lo largo de todo el proceso, singularmente en su fase inicial. Díaz, J., Principios de aportación de parte y acusatorio: la imparcialidad del juez, Comares, Granada, 1996, pp. 214-215, centra su esencia en la distinción entre las funciones acusadoras y las decisorias, que implica la instauración de un proceso de partes, adversarial, de adversarios o partes enfrentadas. v.t. De la Oliva, A., Derecho Procesal Penal, Centro de Estudios Areces, Madrid, 1999, $4^{\mathrm{a}}$ ed., 
de poderes que se evidencian y despliegan en la etapa del juicio, impidiendo que quien acusa y juzga sea una misma persona, lo que, para compatibilizarse con el principio de oficialidad, ha requerido que el Estado asuma tanto la tarea de acusador como la del juez, pero separando esas funciones en dos autoridades estatales distintas, es decir, una autoridad de acusación y un tribunal. Esto es lo que se conoce como "principio acusatorio formal" 16 . De esa manera, si el Magistrado que ordena al MP cumplir las diligencias investigativas, realiza esta actuación durante la investigación -al reabrirse para estos efectos-, sin tampoco pronunciarse respecto de la pertinencia de formular una acusación -de darse una petición de forzamiento del querellante, esta solo se estudiará al cerrarse nuevamente la investigación-, ni tampoco poder integrar el Tribunal de Juicio Oral, en caso de que se llegue a esa instancia -por expresa prohibición del artículo 196, inciso $3^{\circ}, \mathrm{N}^{\circ} 3$ del Código Orgánico de Tribunales-, no se advierte de qué manera el principio acusatorio puede verse vulnerado o siquiera puesto en riesgo. Además, como explica Horvitz ${ }^{17}$, "el fundamento de esta norma no constituye un resabio inquisitivo del legislador, pues no faculta al juez para disponer nuevas diligencias de investigación, sino únicamente aquellas solicitadas por las partes y no realizadas por el fiscal". Agrega esta autora que "esta atribución judicial tiene por fin controlar que el ministerio público haya cumplido debidamente con el principio de objetividad e investigado todos aquellos hechos y circunstancias pertinentes alegados por las partes mediante sus solicitudes de investigación" 18 .

De cualquier forma, esta reapertura de la investigación será improductiva si a la sazón la diligencia que interesa al querellante puede ya no cumplir su objetivo por haberse alterado

p. 43. Un sector de nuestra doctrina, a la siga de la tradición jurídica continental ya apuntada, encapsula en general los rasgos definitorios de lo acusatorio en torno a la separación de las funciones de acusar y juzgar, la exigencia de acusación previa al juicio, y la división del proceso en dos fases que se atribuyen a órganos distintos, v. Horvitz, M. I., "Algunas formas de acuerdo o negociación en el Proceso Penal: Tendencias del Derecho penal comparado”, en Revista de Ciencias Penales, vol. XXXIX, 1994, p. 29; López, J., Derecho Procesal Penal, Santiago, Editorial Jurídica, 2005, T. I, p. 43; Maturana, C., y Montero, R., Derecho Procesal Penal, Legal Publishing, Santiago, 2010, T. I, pp. 91 y ss; y Castro, C., Resabios Inquisitivos en el Proceso Penal Chileno, Metropolitana, Santiago, 2010, pp. 49 y ss.

${ }^{16}$ López, J., Derecho Procesal Penal, Editorial Jurídica, Santiago, 2005, T. I, p. 44.

${ }^{17}$ Horvitz, M. I., Derecho Procesal Penal, Editorial Jurídica, Santiago, 2005, T. I., p. 579.

18 Abona la opción de nuestro legislador el que mecanismos similares puedan hallarse en procesos de corte acusatorio en el derecho comparado, v.gr. las facultades que se conceden al ofendido frente a la solicitud de archivo del Ministerio Público contempladas en los artículos 408.3 y 410 del Código Procesal Penal italiano. El procedimiento portugués, luego de la inquérito desarrollada por el Ministerio Público, considera una fase eventual llamada instrucao (Arts. 17 y 286 a 310 Código Procesal Penal portugués), dirigida por el juez de instrucción y que tiene por objeto la comprobación judicial de la decisión del Ministerio Público de deducir acusación o de archivar el inquérito. Aun cuando esta fase se abre a demanda de las partes, tiene carácter autónomo, es decir, el juez de instrucción no está limitado por las diligencias de investigación solicitadas por las partes. Asimismo, el Código Procesal Penal Modelo para Iberoamérica permite al querellante, dentro del procedimiento intermedio, requerir al tribunal que practique los medios de prueba que estime haya omitido el Ministerio Público en su instrucción (Arts. 269 y 727). 
o desaparecido la evidencia o ya no ser posible conseguir algún testimonio ${ }^{19}$. De ese modo, la acusación que pudiera deducir el ofendido, sea conjuntamente con el MP o autónomamente mediante el forzamiento de la acusación, a la postre depende casi completamente de la calidad de la investigación llevada adelante por este organismo, con lo que pareciera que su ejercicio de la acción penal así como su rol de poderoso puntal del cumplimiento del principio de obligatoriedad de la acción penal se ven seriamente desmejorados ${ }^{20}$.

\section{SOLICITUd DE SOBRESEIMIENTO Y CONTROL JURISDICCIONAL DE LOS PRESUPUESTOS PROCESALES DEL SOBRESEIMIENTO}

Una vez ya firme el cierre de la etapa de investigación, como antes referimos, el MP puede adoptar dos decisiones distintas a la acusación, esto es, solicitar el sobreseimiento de la causa o no perseverar en el procedimiento.

Una petición de sobreseimiento del MP que se aparte del mérito fáctico o jurídico de la investigación debe ser desestimada por el órgano jurisdiccional, pues estos aspectos objetivos están sujetos a su ponderación y revisión, previo debate en que serán oídas todas las partes, incluyendo la querellante (Arts. 249, 250 y 252 del CPP) ${ }^{21}$. Así se ha dicho que no basta una mera opinión del fiscal compartida por el imputado acerca de la concurrencia de la causal de sobreseimiento si ella no fluye de los antecedentes concretos de la investigación, los que debe examinar y ponderar el juez en su resolución. Sostener lo contrario permitiría que por esta vía se burlaran los límites temporales y procesales para la aplicación del principio de oportunidad reglado del artículo 170 del CPP, pudiéndose llegar a un principio de oportunidad discrecional encubierto no aceptado por nuestro legislador, bajo la argucia de una petición de sobreseimiento definitivo amparado en una causal compartida o convenida por los intervinientes del proceso penal ${ }^{22}$,

${ }^{19}$ Recordemos que la ley procesal ha radicado solo en el MP la posibilidad de requerir la recepción de prueba anticipada (Art. 191 del CPP).

${ }^{20}$ Tal desajuste del proceso es cuestionado por Martín, J., El ministerio fiscal como director de la investigación oficial en el Proceso Penal, Publicaciones del Real Colegio de España, Bolonia, 2005, p. 288, cuando analiza el sistema español, señalando que la atribución de la dirección de la investigación al Ministerio Fiscal no puede suponer que las acusaciones no oficiales, a los efectos de que se abra el juicio oral y de fundamentar su acusación, dependan completamente de la investigación que haya realizado otro órgano público.

${ }^{21}$ Para una confrontación del sobreseimiento en el Código de Procedimiento Penal de 1906 y el CPP, v. Maturana, C., "El Sobreseimiento", en Revista de Derecho Procesal, No 20, 2005, pp. 337-367. Un examen de las causales de sobreseimiento definitivo contenidas en el artículo 250 del CPP, en Aguilar, C., Manual de Derecho Procesal Penal Oral, Metropolitana, Santiago, 2004, T. I, pp. 396-408; y Oliver, G., “¿Constituye un orden de prelación el listado de causas de sobreseimiento definitivo del artículo 250 del Código Procesal Penal?", en Revista de Derecho, Pontificia Universidad Católica de Valparaíso, vol. XXXI, 2008, pp. 357-366.

${ }^{22}$ Maturana, C., "El Sobreseimiento”, en Revista de Derecho Procesal, No 20, 2005, pp. 342. Al respecto, Piedrabuena, G., Introducción a la Reforma Procesal Penal. Fallos del Mes, Santiago, 2000, p. 24, señaló que "en caso de discrepancia entre el Ministerio Público y el juez de control sobre la decisión del sobreseimiento debería primar la decisión jurisdiccional por sobre la decisión de un funcionario no jurisdiccional”. En contradicción con esa opinión que compartimos, la SCA de Stgo., Rol No 1.758-2007, de 14.8.2007 ha 
a la que el JG resignadamente debería limitarse a sancionar u homologar. La solicitud de sobreseimiento por esta vía dejaría su condición de acto de obtención, mudando a acto de causación por el que las partes pueden convenir el término anómalo del proceso.

El Proyecto de CPP no permitía al juez rechazar la solicitud de sobreseimiento del fiscal, sino solo sustituir la causal o tipo de sobreseimiento (Art. 346), cuestión que ya Garrido Montt ${ }^{23}$ estimaba inconstitucional al imponer al juez una decisión, desconociendo su facultad privativa de juzgar ${ }^{24}$.

Pero es más, incluso antes del pronunciamiento jurisdiccional, si el querellante particular se opusiere a la solicitud de sobreseimiento formulada por el Fiscal, la ley procesal prevé la remisión de los antecedentes al Fiscal Regional, a objeto que este revise la decisión del persecutor a cargo de la causa. Si la primera autoridad, dentro de los 3 días siguientes, decidiere que el MP formulará acusación, lo hará dentro de 10 días. Pero si ratificare la decisión del fiscal a cargo del caso, el juez puede todavía autorizar que la acusación correspondiente sea formulada por el querellante si estimare que no procede decretar el sobreseimiento correspondiente (Art. 258 del CPP) ${ }^{25}$.

En lo que atañe al régimen recursivo, la víctima se encuentra expresamente legitimada para impugnar el sobreseimiento temporal o definitivo, aun cuando no hubiere intervenido en el procedimiento (Art. 109 letra f) del CPP).

resuelto que es el MP "el órgano que está en situación de poder evaluar con mayor certeza si concurren o no los requisitos para decretar el sobreseimiento definitivo".

${ }^{23}$ Garrido, M., "La instrucción penal. Investigación y formalización de la instrucción”, en AAVV, El Nuevo Proceso Penal Chileno, Universidad de Concepción, Facultad de Ciencias Jurídicas y Sociales, Dpto. de Derecho Procesal, 2000, p. 135.

${ }^{24}$ Piedrabuena, G., Introducción a la Reforma Procesal Penal. Fallos del Mes, Santiago, 2000, p. 48, igualmente criticaba en esta parte el Proyecto de CPP por incluir algunas atribuciones al MP que son dudosamente jurisdiccionales, tales como las relativas a que este organismo impone, por regla general, al juez su decisión de sobreseer en la causa, es decir, de no iniciar un juicio penal mediante la acusación.

${ }^{25}$ A diferencia de otros ordenamientos, v. Armenta, T., Sistemas Procesales Penales. La justicia penal en Europa y América. ¿Un camino de ida y vuelta?, Marcial Pons, Madrid, Barcelona, Buenos Aires, 2012, p. 215, el que el caso avance solo con el impulso de la víctima cuando el Fiscal pide el sobreseimiento, en el proceso chileno, no transforma el delito objeto de la acusación particular en un delito de acción privada.

Respecto de la posibilidad de que el querellante pueda forzar la acusación aun a falta de formalización de la investigación, si hay querella previa contra el imputado -cuestión rechazada por la mayoría de nuestra doctrina-, los jueces disidentes en SCS, Rol No 4.909-2013, de 17.9.2013, manifestaron que "la satisfacción de la obligación de congruencia que grava al acusador se soluciona confrontando la querella y acusación deducida una vez autorizado su forzamiento, actuaciones que permiten hacer efectivos los derechos de información y defensa que la formalización de la investigación cautela, así como los límites fácticos a los que deben sujetarse los juzgadores para emitir la decisión que les ha sido válidamente requerida mediante el ejercicio de las acciones que el ordenamiento jurídico procesal coloca a disposición del ofendido y de las personas que la ley señala". Una posición abiertamente contraria a analogar para estos efectos la comunicación realizada mediante la querella a aquella correspondiente a la formalización, en SCA de San Miguel, Rol $\mathrm{N}^{\circ}$ 1.249-2006, de 17.11.2006. Pero, al contrario, tal formalización no es exigida previamente para decretar el sobreseimiento, v. SCA de Antofagasta, Rol No 186-2007, de 14.8.2007; SSCA de Stgo., Rol No 1.3492007, de 26.6.2007, Rol No 1.348-2007, de 27.6.2007, Rol No 1.674-2007 de 7.8.2007, Rol No 1.7582007, de 14.8.2007, Rol No 1.936-2007, de 3.9.2007, Rol No 1.876-2009, de 30.9.2009. Oo. SCA de La Serena, Rol No 276-2006, de 5.10.2006. 
Ahora bien, si en la causa no se ha hecho parte el ofendido como querellante, de manera de que este pueda echar mano al instituto del forzamiento de la acusación al que tanto hemos aludido, el MP puede terminar, en los hechos, imponiendo su criterio jurídico -o discreción- sobre aquel del tribunal que rechace el sobreseimiento definitivo por estimar que los acontecimientos investigados sí constituyen delito, o que no está claramente establecida la inocencia del imputado (Art. 250 letras a) y b) del CPP). Y es la misma ley la que abre las puertas a la discrecionalidad del persecutor público, al autorizarle el artículo 256 del CPP, frente al rechazo de la solicitud de sobreseimiento -sin distinguir la causal de este- para ejercer la atribución de la letra c) del artículo 248 del CPP, esto es, no perseverar en el procedimiento, decisión respecto de la que, como veremos en seguida, el tribunal de garantía está despojado de herramientas oficiosas para enmendar.

Una situación como la enunciada precedentemente fue parte de los hechos objeto de pronunciamiento en sentencia del Tribunal Constitucional, Rol No 1341-2009, de 15 de abril de 2010 (correspondientes a causa RUC No 0810018505-k del JG de Pucón), donde luego de presentada la querella por el ofendido, el Fiscal solicita al tribunal el sobreseimiento definitivo de la causa por no ser los hechos constitutivos de delito, petición que el tribunal desestima. Sin embargo, a renglón seguido el MP cierra la investigación y comunica su decisión de no perseverar en el procedimiento.

\section{ANÁlisis de la DENOMINADA DECISIÓN DE NO PERSEVERAR EN EL PROCEDIMIENTO}

La decisión del MP de no perseverar en el procedimiento, que este comunica al final de la fase de investigación, se sustenta -por así disponerlo el artículo 248 letra c) del CPP - en la carencia de antecedentes suficientes para fundar una acusación. $\mathrm{O}$, con mayor precisión, según el modelo ideado por los redactores del CPP, si el cúmulo de antecedentes recopilados al cabo de la investigación no son suficientes o idóneos para establecer claramente la inocencia del imputado, de manera que no permitan decretar el sobreseimiento definitivo de la causa (Art. 250 letra b) del CPP), ni proporcionan fundamento serio para el enjuiciamiento del imputado (Art. 248, inc. $1^{\circ}$ letra b), del $\mathrm{CPP}$ ), en cuyo caso procede que el fiscal no persevere en el procedimiento.

De ese modo, esta decisión de no perseverar es la procedimentalización de un estado intelectual de duda en que se halla empantanado el instructor estatal al final de las pesquisas, al no lograr un fundamento serio para el enjuiciamiento del sujeto formalizado, como tampoco la certeza de no culpabilidad que le permita instar por el sobreseimiento definitivo de la causa al no aparecer claramente establecida la inocencia del imputado (Art. 250 letra b) del CPP). Como sentencia Núñez ${ }^{26}$, la decisión de no perseverar se funda "en la no existencia de un mínimo de pruebas idóneas, las cuales por su vaguedad

${ }^{26}$ Nuñez, J.C., Tratado del Proceso Penal y del Juicio Oral, Metropolitana, Santiago, 2003, T. II, p. 150. 
o ineficacia hagan presumible la inutilidad de llevar el caso al juicio oral, al llevar al investigador a una duda razonable de que aquellas no podrán completarse o consolidarse, ni servir como germen o fuente de otras probanzas idóneas que puedan dar al tribunal oral en lo penal la certeza que la ley exige para poder condenar" 27.

De lo expuesto aparece de manifiesto que la decisión del MP de no perseverar en el procedimiento responde únicamente a una determinación técnica -insuficiencia de antecedentes-y no a discrecionalidad política u oportunidad-desinterés social en su persecución, sobrecarga de la Fiscalía, etc.-. Sin embargo, la ausencia de un control judicial que recaiga sobre el mérito de dicha decisión administrativa del órgano persecutor deja un flanco abierto para el ingreso de razones de oportunidad o políticas, que solo puede ser remediado conforme a nuestro ordenamiento vigente, mediante la intervención activa de la parte querellante mediante el forzamiento de la acusación.

\section{Imprevisión normativa de control jurisdiccional de mérito}

La omisión de un control jurisdiccional de oficio, directo y estricto sobre esta decisión del MP, fue una deliberada opción de nuestro legislador al estimar que se opondría al sistema que se estaba implantando con la nueva regulación procesal penal. En efecto, el Proyecto de CPP no contemplaba el instituto en comento, al seguir un modelo similar al contenido en el Código Procesal Penal Modelo para Iberoamérica ${ }^{28}$, considerando solo el sobreseimiento definitivo y temporal (Arts. 340 y 342), y por tanto, siempre sometido a la decisión jurisdiccional. Se comprendían dentro de las causales del sobreseimiento

${ }^{27}$ Este parecer es compartido en SSTC, Rol No 1.341-2009, de 15.04.2010 (cons. 52 ${ }^{\circ}$ ), Rol No $1.404-$ 2009, de 18.05.2010 (cons. $23^{\circ}$ ) y Rol No 1.394-2009, de 13.7.2010 (cons. 23º). En las palabras de Arocena, G., "De la acusación, del in dubio pro reo y de la garantía del debido proceso", en Cafferata, J., y Arocena, G., Temas de derecho Procesal Penal (Contemporáneos), Mediterránea, Córdoba, 2001, 189-190, esta decisión de no perseverar transluce un estado de duda "insuperable" del Fiscal, estado intelectual que se verifica cuando, venciendo todos los términos de la investigación penal preparatoria y sus prórrogas, no hubiere suficiente fundamento para elevar la causa a juicio y no fuere razonable, objetivamente, prever la incorporación de nuevas pruebas. Otro acertado enfoque apunta Cafferata, J., Cuestiones actuales sobre el Proceso Penal, Editores del Puerto, Buenos Aires, 2000, $3^{\text {a }}$ ed., p. 38, para quien el sobreseimiento por duda insuperable evidencia una decisión de política procesal, con sentido de oportunidad, basado en ciertos fundamentos (evitarle al Estado gastos inútiles y al acusado la "pena del banquillo"), lo que ha determinado que se lo señale como un caso de "discrecionalidad técnica".

${ }^{28}$ El que distingue entre sobreseimiento (o absolución anticipada), procedente cuando "no existiere, razonablemente, la posibilidad de incorporar nuevos elementos de prueba y fuere imposible requerir, fundadamente, la apertura del juicio" (Art. 278.2), y la clausura provisional (archivo), concurrente cuando "no correspondiere sobreseer y los elementos de prueba resultaren insuficientes para requerir la apertura del juicio", debiendo en este caso "mencionar, concretamente, los elementos de prueba que se espera poder incorporar" (Art. 281). Según este modelo, "cuando nuevos elementos de prueba tornen viable la reanudación de la persecución penal, para arribar a la apertura del juicio o al sobreseimiento (absolución anticipada), el tribunal, a pedido del ministerio público o de alguno de los intervinientes, podrá permitir la reanudación de la investigación" (Art. 281 inc. $3^{\circ}$ ). Sobre el control judicial de estas decisiones en el Código Procesal Penal modelo para Iberoamérica, v. Álvarez, A., "El control de la acusación. Pena y Estado", en Revista Latinoamericana de Política Criminal, Año 2, No 2, 1997, pp. 15-32. 
temporal que nos interesan ahora: "a) Cuando los antecedentes reunidos durante la investigación no fueren suficientes para fundar una acusación y dicha investigación no pudiere seguir adelante en forma inmediata, habiendo, no obstante, motivos para esperar el surgimiento de nuevos antecedentes con posterioridad", y del sobreseimiento definitivo: "g) Cuando los antecedentes reunidos durante la investigación no fueren suficientes para fundar una acusación y se encontrare vencido el plazo del artículo 337 [plazo de dos años para declarar el cierre de la investigación], o no existiere, razonablemente, la posibilidad del surgimiento de nuevos antecedentes que permitan lograr el esclarecimiento de los hechos investigados". En el Proyecto de CPP entonces, en ausencia de antecedentes suficientes para acusar se debía distinguir si existían motivos para pensar que en el futuro estos iban a surgir: si los había, procedía sobreseer temporalmente, si no, definitivamente. Pero el primer sobreseimiento, al cabo de dos años, igualmente devenía en definitivo. Este cambio -en relación con el Código de Procedimiento Penal de $1906^{29}$ - fue justificado en el Mensaje del Proyecto de CPP señalando que el anterior sobreseimiento temporal "mantiene indefinidamente la posibilidad de la persecución en su contra [del imputado] con la incertidumbre que ello implica. Este último solo podrá liberarse de esta carga en cuanto sea capaz de probar positivamente su inocencia -con esto se produce una distorsión de uno de los componentes básicos de la presunción de inocencia como es el que la carga de la prueba recae sobre el acusador- o cuando transcurran los plazos de prescripción”.

Fue en el segundo informe de la Comisión del Senado donde luego de eliminar la mentada causal de sobreseimiento temporal se introdujo esta tercera alternativa para el MP, argumentándose que "esta materia dice relación con el modelo de sistema por el que se opte, y que fue determinado por el artículo 80 A [actual artículo 83] de la Constitución Política, que le entrega al ministerio público la exclusividad de la investigación. En consecuencia, quien decide si procede o no la acusación y si la investigación está completa debe ser el ministerio público, el juez y las partes podrán pedir al superior jerárquico del fiscal, que es el fiscal regional, que revise la situación y este responderá por sus decisiones (-). Al mismo tiempo, incluyó una tercera opción para el fiscal, consistente en que comunique la decisión del ministerio público de no perseverar en el procedimiento, por no haberse reunido antecedentes suficientes para fundar una acusación, esto es, la circunstancia que se contempla al comienzo de la última causal de sobreseimiento definitivo. En tal caso, por consiguiente, no se decretará sobreseimiento, sino que, al igual que ocurre con la formalización de la investigación, se tomará conocimiento de

${ }^{29}$ El Código de Procedimiento Penal de 1906, sin contemplar expresamente un instituto como la decisión de no perseverar, contiene entre las causales de sobreseimiento definitivo y temporal las siguientes: cuando, en el sumario, no aparezcan presunciones de que se haya verificado el hecho que dio motivo a formar la causa; cuando no resulte completamente justificada la perpetración del delito que hubiere dado motivo a la formación del sumario, y; cuando, resultando del sumario haberse cometido el delito, no hubiere indicios suficientes para acusar a determinada persona como autor, cómplice o encubridor (Arts. $408 \mathrm{~N}^{\circ} 1$ y 409 $\mathrm{N}^{\circ} 1$ y 2 , respectivamente). 
una decisión del ministerio público, sobre la cual no le corresponderá pronunciarse al juez de garantía, sin perjuicio de la ulterior revisión que de ella pudiere efectuarse" 30 .

De esta manera, en el modelo ideado por el legislador, la decisión de no perseverar en el procedimiento ostenta un puro carácter administrativo y no se encuentra sujeta a revisión o control judicial sobre su mérito, sino solo en cuanto a sus presupuestos adjetivos, esto es, que la investigación se encuentre cerrada y que se adopte dentro del término de 10 días desde dicha clausura ${ }^{31}$. Desde esa perspectiva, es más bien la comunicación de una decisión ya adoptada administrativamente y no una solicitud de pronunciamiento judicial sobre la misma, pues el Fiscal no está obligado a motivarla, y el tribunal tampoco puede cuestionarla o revisarla, conclusión en la que parece converger nuestra doctrina ${ }^{32}$, al igual que nuestros tribunales superiores ${ }^{33}$.

A mayor abundamiento, el estudio de las normas del párrafo $7^{\circ}$, título I del libro II del CPP confirma nuestro aserto, al distinguir el legislador entre la actuación del tribunal frente a una solicitud de sobreseimiento y una comunicación de no perseverar. Si bien frente a ambas se convoca a audiencia, únicamente ante la primera el legislador requiere al juez pronunciarse ya sea acogiéndola, rechazándola, o sustituyéndola por otra causal, y otorga además a los intervinientes la posibilidad de apelar dicha decisión,

\footnotetext{
${ }^{30}$ Un compendio de la historia y discusión parlamentaria del precepto en comento en Novoa, J.P, “Análisis de la facultad del Ministerio Público de no perseverar en la investigación”, en Revista Procesal Penal, $\mathrm{N}^{\circ} 27,2004$, p. 29.

31 Así lo confirma SCA de Stgo., Rol N².703-2010, de 10.1.2011 al resolver que "la decisión de no perseverar el conocimiento hecho por el Ministerio Público no tiene la naturaleza de una resolución”, y SCA de Rancagua, Rol No 145-2004, de 11.11.2004, al señalar que "es admisible concluir que el examen que pueda hacer el juez sea puramente formal, en cuanto a que se encuentre realmente cerrada la investigación y quizás que esta haya sido previamente formalizada (-)”. v.t. SSCA Rancagua Rol Nº 358-2011 de 7.11.2011 y Rol No 282-2012 de 23.7.2012.

32 v. Aguilar, C., Manual de Derecho Procesal Penal Oral, Metropolitana, Santiago, 2004, T. I, p. 413; Novoa, J.P., “Análisis de la facultad del Ministerio Público de no perseverar en la investigación”, en Revista Procesal Penal, No 27, 2004, pp. 23-24; Maturana. C., "El Sobreseimiento”, en Revista de Derecho Procesal, N² 20, 2005, p. 357; Fernández, M. Á., La nueva justicia penal frente a la Constitución, LexisNexis, Santiago, 2006, p. 206; Cerda, R., y Hermosilla, F, El Código Procesal Penal. Comentarios, Concordancia y Jurisprudencia,

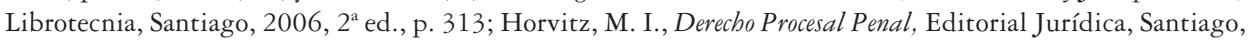
2005, T. I, p. 585, quien reafirma que "la decisión sobre el mérito de los antecedentes de la investigación es, pues, de exclusiva competencia del Ministerio Público y no cabe, en consecuencia, un pronunciamiento ulterior del juez ni, evidentemente, recursos jurisdiccionales en contra de la misma”. v.t. SCA de Rancagua, Rol No 183-2009, de 2.7.2009 al decidir que: “(-) siendo además esta facultad de carácter privativo y excluyente, de modo que el juez de garantía no puede resolver no aprobar la decisión del Ministerio Público”.

33 v. SCS, Rol No 4.944-2011, de 22.9.2011; SCA de Stgo., Rol No 2.628-2006, de 16.1.2007; SCA de Antofagasta, Rol No 256-2008, de 7.11.2008; SCA de Sn. Miguel, Rol No 1.152-2008, de 15.12.2008; SCA de Rancagua, Rol No 5-2007, de 16.2.2007; SCA de Valdivia, Rol No 75-2009. de 4.3.2009; y, SSCA de Concepción, Rol No 350-2007, de 27.7.2007, Rol No 368-2009, de 13.8.2009, Rol No 636-2009, de 23.12.2009, Rol No 439-2011, de 7.10.2011, y Rol No 397-2012, de 17.8.2012. La STC, Rol No 1.341-2009, de 15.4.2010 (cons. $55^{\circ}$ ), por su parte, ratifica que "la decisión de no perseverar en el procedimiento no está sometida a la aprobación del juez de garantía, y en eso se diferencia del sobreseimiento. Dicha característica tiene relación con la naturaleza investigativa de la facultad de no perseverar y con la lógica de la Reforma de separar funciones administrativas y jurisdiccionales en distintos órganos".
} 
todo lo que no ocurre frente a la comunicación de no perseverar, precisamente porque no hay una evaluación judicial del mérito de la resolución administrativa ${ }^{34}$. A lo más podría observar y corregir el tribunal vicios formales o procedimentales que impidieran efectuar dicha comunicación. Por ello estamos junto a Maturana y Montero ${ }^{35}$, cuando propugnan que ante esta comunicación el juez debe dictar una resolución revocando las medidas cautelares decretadas, sin que sea necesario declarar sin efecto la formalización, pues la ley dispone ese efecto de pleno derecho por la mera comunicación del MP de su decisión de no perseverar en el procedimiento (Art. 248, inc. final, del CPP).

La decisión de no perseverar en el procedimiento -así como la formalización de la investigación ${ }^{36}$ - constituye por tanto, una actuación administrativa contenedora de conclusiones y no de requerimientos, porque se manifiesta en forma de dictámenes, expresando una opinión definitiva sobre el punto o cuestión de que se trata ${ }^{37}$. Como no se busca con ella obtener un pronunciamiento del tribunal, no se acompaña de una exposición de razones -más allá de la genéricamente prevista en la ley-, pues la ausencia de estas no podría acarrear su rechazo por el órgano jurisdiccional, a diferencia de los requerimientos.

${ }^{34}$ En ese orden -la improcedencia de la apelación- se han pronunciado SSCA de Stgo., Rol N ${ }^{\circ} 797$ 2007, de 16.4.2007, Rol No 1.254-2007, de 11.6.2007, Rol No 2.703-2010, de 10.1.2011 y Rol No 8832012, de 14.5.2012; y, SCA de Concepción, Rol No 439-2011, de 7.10.2011. También Aguilar, C., Manual de Derecho Procesal Penal Oral, Metropolitana, Santiago, 2004, T. I, p. 416. Pero es posible igualmente ubicar autores y jurisprudencia en contrario, v. Núñez, J. C., Tratado del Proceso Penal y del Juicio Oral, Metropolitana, Santiago, 2003, T. II, p. 153, quien indica que el juez debe "aprobar" la decisión del fiscal de no perseverar en el procedimiento, resolución que, por poner término a este, sería apelable. También SSTC, Rol No $1.404-$ 2009, de 18.5.2010 (cons. 38 ), y Rol No 1.394-2009, de 13.7.2010 (cons. 35 ${ }^{\circ}$ ), estimando que la Corte de Apelaciones puede controlar, por vía de apelación, "la resolución del tribunal de garantía que se expida sobre la decisión de no perseverar del ente persecutor". En SCS, Rol Nº 6.742-2008, de 26.2.2009 se determinó que la resolución que tuvo por comunicada la decisión del MP de no perseverar en el procedimiento, por haber sido dictada por un JG en el ejercicio de sus funciones, es una actuación de carácter jurisdiccional, y es de aquellas que hace imposible la prosecución del procedimiento si no le ha precedido la formalización de la investigación, al impedir esto el forzamiento de la acusación por el querellante y, en consecuencia, la continuación del procedimiento. Afirmando la existencia de un pronunciamiento jurisdiccional apelable, también SSCA de Rancagua, Rol N ${ }^{\circ}$ 145-2004, de 11.11.2004 y Rol No 183-2009, de 2.7.2009; SSCA de Sn. Miguel, Rol No 1450-2008, de 25.11.2008, Rol No 26-2011, de 4.3.2011, y Rol No 739-2012, de 19.6.2012; SSCA de Arica, Rol No 32-2011, de 28.2.2011, Rol No 137-2012, de 4.6.2012, y Rol No 147 2012, de 6.6.2012; y, SCA de Concepción, Rol No 239-2005, de 29.4.2005.

${ }^{35}$ Maturana, C., y Montero, R., Derecho Procesal Penal, Legal Publishing, Santiago, 2010, T. II, p. 674.

36 Un lector atento reparará que la decisión de no perseverar es equivalente a la formalización de la investigación en varios aspectos: ambas son comunicaciones administrativas que unilateralmente realiza el MP no encaminadas a obtener un pronunciamiento judicial que las apruebe y, atendida dicha naturaleza común, no puede forzárseles a formalizar o perseverar en la investigación -mediante la acusación en este caso- si el Fiscal instructor ha decidido lo contrario, solo admitiendo la ley compeler la formalización en garantía del imputado y la subrogación del Fiscal por el querellante en la acusación.

37 Contienen requerimientos, en cambio, los actos del MP que se manifiestan como reclamación ante el órgano jurisdiccional para que proceda conforme a lo peticionado: instancias con predominio del elemento volitivo por las que se reclama una concreta y determinada decisión. Acerca de esta materia, v. Claría, J., Derecho Procesal Penal, Rubinzai-Culzoni, Buenos Aires, T. II, p. 275. 


\section{Forzamiento de la acusación}

En nuestro ordenamiento procesal penal, una especie de control de mérito sobre la decisión del MP de no perseverar en el procedimiento puede efectuarse por el juez solo por vía indirecta, y únicamente a petición de otros intervinientes, especialmente el querellante, al resolver la solicitud de reapertura de la investigación ya comentada y de forzamiento de la acusación que trataremos ahora ${ }^{38}$.

En efecto, ante una errónea decisión de no perseverar en el procedimiento, pues la investigación sí ha reunido antecedentes que permiten fundar con seriedad el enjuiciamiento del sujeto formalizado, al igual que respecto del sobreseimiento, el juez puede autorizar al querellante a formular su acusación, de conformidad al artículo 258 del CPP, norma que debe su origen a disposiciones similares de la Ordenanza Procesal Penal alemana $(\S \S 172-177)$, y que se fundamenta en "la posibilidad de que la víctima promueva el control, por parte de un tribunal independiente, de la vigencia del principio de legalidad que corresponde cautelar al ministerio público"39. La propuesta del Ejecutivo establecía que "El juez de control de la instrucción podrá ordenar al fiscal la formulación de la acusación, cuando lo solicite el querellante y siempre que los antecedentes acumulados

38 Ortells, R. M., "Cuatro aproximaciones al nuevo proceso penal chileno desde la perspectiva del Proceso Penal en países de la Unión Europea”, en AAVV, El Nuevo Proceso Penal Chileno, Facultad de Ciencias Jurídicas y Sociales, Dpto. de Derecho Procesal. Universidad de Concepción, 2000, pp. 309, ve necesario un control judicial en un régimen de dirección de la instrucción llevado por el MP, para garantizar el efectivo cumplimiento de las funciones de la instrucción, lo que exigiría: a) que la posibilidad de participación de los acusadores no oficiales en la investigación sea judicialmente protegida frente a las negativas del MP, y b) que se sometan al juicio de un órgano jurisdiccional las decisiones de no ejercicio de la acción penal adoptadas por el MP. Bofill, G. J., "El juicio oral. Preparación y desarrollo", en AAVV, El nuevo proceso penal chileno, Universidad de Concepción, Facultad de Ciencias Jurídicas y Sociales, Dpto. de Derecho Procesal, 2000, p. 205, en cambio, percibe como problemáticos los controles positivos por cuanto la resolución de mérito emitida por el JG puede transformarse en un antecedente para el TJOP. Castro, C., Resabios Inquisitivos en el Proceso Penal Chileno, Metropolitana, Santiago, 2010, p. 253, por su parte, señala los peligros que ello supone si el mismo JG que visó la acusación del querellante luego es el juzgador del procedimiento abreviado, lo que nos retrotraería a la estructura del sistema inquisitivo. En Alemania, precisamente se ha discutido el valor de la fase intermedia del proceso, donde se decide la apertura del procedimiento o su sobreseimiento, fundamentalmente por el peligro de prejuzgar que tal análisis implica, aunque al tratarse de una posibilidad más de que el imputado pueda luchar contra la apertura del procedimiento principal, se ha expresado que no parece inapropiado defender su mantenimiento, v. Gómez, J-L., El Proceso Penal Alemán, Introducción y Normas Básicas, Bosch, Barcelona, 1985, p. 158 y 234. Para una síntesis y sistematización de los mecanismos de control del ejercicio de la acusación, v. Armenta, T., Sistemas Procesales Penales. La justicia penal en Europa y América. ¿Un camino de ida y vuelta?, Marcial Pons, Madrid, Barcelona, Buenos Aires, 2012, pp. 76-77. Respecto de este tipo de procedimientos de control en el sistema italiano, contemplados en los artículos 408-415 de su texto procesal, v. Morosi, G., "El sistema procesal penal italiano", en Hendler, E., (dir.), Sistemas Procesales Penales Comparados, Ad Hoc, Buenos Aires, 1999, pp. 178 y ss; en cuanto con el procedimiento ordinario español, artículos 642 a 644 de la Ley de Enjuiciamiento Criminal, v. Gimeno, V., Moreno, V., y Cortés, V., Derecho Procesal Penal $3^{a}$ edición, Colex, Madrid, 1999, p. 858; y en relación con el procedimiento alemán, $\S \S 170$ y ss. de su Ordenanza Procesal, v. Armenta, T., Criminalidad de bagatela y principio de oportunidad: Alemania y España, Promociones y Publicaciones Universitarias, Barcelona, 1991, pp. 138-140; y Gómez, J-L., El Proceso Penal Alemán, Introducción y Normas Básicas, Bosch, Barcelona, 1985, p. 154.

${ }^{39}$ Horvitz, M., I., Derecho Procesal Penal, Editorial Jurídica, Santiago, 2005, T. I, p. 588. 
en la instrucción constituyeren suficiente fundamento para el enjuiciamiento del imputado" (Art. 346, inc. $4^{\circ}$, del Proyecto de CPP). En el segundo informe de la Comisión del Senado "se ponderó el hecho de que una actitud que podría asumir el fiscal, si es obligado a acusar en contra de su voluntad, es sostener en el juicio su tesis original, sea sobreseimiento u otra, con lo que la acusación carecería de sentido, o desarrollar una labor mínima, que conduciría a la absolución del imputado. Para evitar esa alternativa estudió la conveniencia de que el fiscal sea reemplazado o de que se prescinda del fiscal, y que el acusador particular asuma el rol contradictor de la defensa".

Ya hemos mencionado que en disidencias de fallos de la Corte Suprema se ha sostenido que, aun a falta de formalización de la investigación, el ofendido podrá forzar la acusación si le antecede una querella, no obstante que nuestra jurisprudencia mayoritaria ha seguido un derrotero diverso, exigiendo igualmente la formalización previa de la investigación para estos efectos ${ }^{40}$. Atendamos ahora a lo siguiente. Manteniéndonos en el contexto del artículo 258 del CPP, para conseguir acusar particularmente, el querellante deberá superar un control de mérito negativo acerca de la seriedad del fundamento de su acusación al que no se halla expuesto el libelo del acusador público ${ }^{41}$, lo que se deduce del carácter facultativo que para el juez tiene la concesión de dicho permiso. Además ya el Proyecto de CPP solo autorizaba la apertura del juicio oral a petición del querellante "siempre que los antecedentes acumulados en la instrucción constituyeren suficiente fundamento para el enjuiciamiento del imputado” (Art. 346) ${ }^{42}$.

${ }^{40}$ Pero al contrario, hoy una vasta doctrina jurisprudencial parece haberse decantado por no exigir la formalización previa a la comunicación de la decisión de no perseverar, v. SSCA de Concepción, Rol No 5262004, de 15.11.2004, Rol No 350-2007, de 27.7.2007, Rol No 368-2009, de 13.8.2009, Rol No 636-2009, de 23.12.2009, y Rol N 397-2012, de 17.8.2012; SCA de La Serena, Rol No 364-2005, de 10.1.2006, SSCA de Stgo., Rol No 2628-2006, de 16.1.2007 y Rol No 360-2007, de 26.2.2007, SCA de Coyhaique, Rol $\mathrm{N}^{0}$ 79-2008, de 25.9.2008, SCA de Sn. Miguel, Rol No 1.152-2008, de 15.12.2008, y SCA de Rancagua, Rol No 183-2009, de 2.7.2009, al igual que la cátedra, por todos, Maturana, C., y Montero, R., Derecho Procesal Penal, Legal Publishing, Santiago, 2010, T. II, p. 675. y Aguilar, C., Manual de Derecho Procesal Penal Oral, Metropolitana, Santiago, 2004, T. I, p. 415, n. 45. La jurisprudencia inicial, hoy superada, deducía la exigencia de formalización previa, a contrario sensu, del texto del artículo 248, inc. $2^{\circ}$, del CPP, el que prescribe que esta comunicación "dejará sin efecto la formalización de la investigación”. Acogió dicha exigencia, por ejemplo, la SCA de La Serena, Rol No 133-2005, de 28.06.2005; SSCA de Rancagua, Rol $\mathrm{N}^{\circ}$ 5-2007, de 16.2.2007, Rol N³58-2011, de 7.11.2011, y Rol No 282-2012, de 23.7.2012; y SCA de Arica, Rol No 32-2011, de 28.2.2011.

${ }^{41}$ Nuestro CPP se aleja en este punto de sus modelos del derecho comparado, según se explica en el Mensaje $\mathrm{N}^{\circ}$ 110-331, cuestión que avalaban ya los estudios que antecedieron al CPP, v. Vargas, J.E., "El Ministerio Público en el proceso penal, a la luz de la sensación de crisis en la justicia criminal”, en AAVV, El Ministerio Público para una nueva justicia criminal, Fundación Paz Ciudadana. Escuela de Derecho Universidad Diego Portales. Corporación de Promoción Universitaria, Santiago, 1994, p. 200. Horvitz, M. I., Derecho Procesal Penal, Editorial Jurídica, Santiago, 2005, T. II, p. 17, llama la atención acerca de la discordancia de la ausencia de este control negativo respecto de la acusación del MP, y sus razones, con la existencia de un control positivo de la acusación por parte del querellante.

${ }^{42}$ Cuando el forzamiento de la acusación se insta ante la solicitud de sobreseimiento del MP, este control de mérito se efectúa primero de manera indirecta, mediante la resolución que rechaza el sobreseimiento, lo que no obsta a que posteriormente haya un nuevo examen relativo a la viabilidad de la acusación en relación con el material probatorio reunido. 
Esta discriminación entre el control jurisdiccional sobre la acusación del MP y la del querellante puede obedecer al distinto carácter de la actividad de ambos, pues mientras aquel se rige por el principio de objetividad y representa los intereses de la colectividad, este generalmente actúa interesadamente en representación de intereses particulares. Sobre el punto, Maier ${ }^{43}$ nos explica que "la representación privada de un interés estatal no es una figura adecuada y solo constituiría un juego de palabras: a ella le faltaría la objetividad y legalidad que se requiere de la actividad desarrollada por órganos del Estado, en este caso, por la fiscalía" ${ }^{44}$. Nuestro Tribunal Constitucional en principio propugnó un supuesto plano de igualdad en que el artículo 83 de la CPR habría situado al ofendido por el delito y al MP en el ejercicio de la acción penal ${ }^{45}$, apreciación que moderó posteriormente al dictaminar que "el hecho de que la persecución penal provenga de los órganos del Estado, explica que la víctima no pueda ocupar el mismo lugar ni el mismo rol que ocupa el Ministerio Público en el sistema (-) De este modo, a pesar de que no son equivalentes con las facultades del Ministerio, se establecen facultades equiparables para que la víctima pueda hacer valer sus intereses en el proceso. Pero unas son potestades públicas, es decir, poderes jurídicos para imponer conductas, y los otros, derechos" 46 .

Por lo demás, este examen judicial de mérito a que se somete la solicitud del querellante para acusar particularmente protege dos aspectos fundamentales: por un lado, el interés de los posibles acusados para no verse sometidos, sin justificación suficiente, a un juicio oral que, aunque no finalice con una sentencia condenatoria, es causa de desprestigio social y de daños morales y psicofísicos para los mismos -la conocida pena del banquillo-; y por otra parte, se trata de evitar acusaciones insuficientemente fundadas -y la consiguiente apertura del juicio oral-, que corren el riesgo de ser rechazadas con eficacia de cosa juzgada, con la posible consecuencia de que se produzcan situaciones

43 Maier, J., Derecho Procesal Penal II Parte General. Sujetos Procesales. Editores del Puerto, Buenos Aires, 2003, $1^{\text {a }}$ ed., p. 626. En el mismo sentido, respecto de la especial posición que, en su calidad de parte imparcial pueda ostentar el Ministerio Fiscal español dentro del proceso, v. Gimeno, V., Moreno, V., y Cortés, V., Derecho Procesal Penal, Colex, Madrid, 1999, $3^{a}$ ed., p. 75. Para Burgos, J., Modelo y Propuestas para el Proceso Penal Español, ePraxis, Sevilla, 2012, p. 56, el Fiscal, a diferencia del juez, al fin de cuentas es parte, aunque sea en nombre de un interés público, consagrado en la ley. Oo. SCA Valpo., Rol No 62-2014, de 16.1.2014, plantea que se aplican los mismos estándares que al MP y, por tanto, la seriedad de fundamentos corresponde ponderarla al propio querellante.

${ }^{4}$ Sobre los problemas que acarrea para la eficiencia de un de sistema penal acusatorio el atribuir al querellante los mismos derechos del MP, v. Maturana, C., y Montero, R., Derecho Procesal Penal, Legal Publishing, Santiago, 2010, T. I, pp. 324-325.

${ }^{45}$ STC, Rol N $1.380-2009$, de 3.11.2009 (cons. $14^{\circ}$ ).

${ }^{46}$ STC, Rol No 1.341-2009, de 15.4.2010. v.t. sentencia del Tribunal Constitucional español 148/1997, de 2 de septiembre. Análoga idea se sostuvo por la Fiscalía española (Circular 1/1989), en relación con el artículo 790.2 de la Ley de Enjuiciamiento Criminal, al argüir una diferencia de trato entre el Ministerio Fiscal y las restantes partes acusadoras en el procedimiento abreviado, basado precisamente en que la representación pública se rige por los principios de legalidad e imparcialidad, mientras las acusaciones particulares se mueven por intereses parciales y ajenos al interés público, criterio que habría sido acogido por el Tribunal Constitucional español en STC 186/1990 de 15 de noviembre, v. Armenta, T., Estudios sobre el Proceso Penal, Rubinzai-Culzoni, Buenos Aires, 2008, pp. 84-85, n. 9. 
de impunidad total o parcial ${ }^{47}$. La decisión de no perseverar en la investigación, en cambio, precisamente deja expectante la ocasión para que, con nuevos hallazgos, rastros o información, la persecución penal se reactive con el éxito que ahora no tuvo, expectativa que se vería diluida si se permitiera al querellante forzar la acusación sin suficiente aval probatorio.

Prevengamos que todo lo hasta ahora reflexionado dice relación con el rito ordinario, pues a la etapa jurisdiccional del procedimiento simplificado regularmente no le antecede una fase de investigación formalizada, careciéndose por tanto de un momento de cierre de investigación y de instancia procesal para el forzamiento de la acusación -o requerimiento en este caso- ${ }^{48}$ En el supuesto que venimos tratando, si el fiscal considera erróneamente que no hay antecedentes para fundar un requerimiento, simplemente archivará los antecedentes (Art. 167 del CPP), oportunidad en que la víctima podrá instar por la continuación del proceso deduciendo querella (Art. 169 del CPP), y posteriormente forzando la acusación de la manera antedicha.

\section{Hallazgo de nuevos antecedentes}

No es en balde recordar que una vez comunicada la decisión de no perseverar, si el MP toma conocimiento de nuevos antecedentes que ameritarían la reapertura de la investigación, igual que en el archivo provisional, resurge la obligatoriedad del ejercicio de la acción penal y, en consecuencia, de reabrir la investigación y avanzar a la acusación, en su caso.

Pero es factible señalar en este punto que no toda nuestra doctrina comparte la posibilidad de reapertura de la investigación, así es como Horvitz ${ }^{49}$ lo desestima, al postular que solo cabe aguardar que se extinga la acción penal en el plazo respectivo, oportunidad en la que podrá solicitarse el sobreseimiento definitivo de la causa. Por su lado, Maturana y Montero ${ }^{50}$ creen posible volver a formalizar una nueva investigación y solicitar que se decreten medidas cautelares en contra de un imputado, si se presentan diversos antecedentes a aquellos que se contenían en la investigación en que se decidió no perseverar en el procedimiento, argumentando que de lo contrario se arribaría "a una aplicación de principio de oportunidad discrecional encubierto no aceptado por

47 Ortells R. M., "Cuatro aproximaciones al nuevo proceso penal chileno desde la perspectiva del Proceso Penal en países de la Unión Europea”, en AAVV, El Nuevo Proceso Penal Chileno, Facultad de Ciencias Jurídicas y Sociales, Dpto. de Derecho Procesal. Universidad de Concepción, 2000, p. 308.

${ }^{48} \mathrm{Si}$ se siguen en principio las normas adjetivas del proceso ordinario, formalizando la investigación respecto de un delito que conforme al artículo 388 del CPP debiera ser enjuiciado según el procedimiento simplificado, creemos que no procederá el forzamiento de la acusación por el querellante frente a la comunicación de no perseverar que realice el MP, pues la pena que perseguirá el actor particular hará imperativo (Art. 390, inc. $2^{\circ}$, del CPP) mutar nuevamente el procedimiento al rito del simplificado, el que volvemos a recalcar, no contempla la adhesión a la acusación, la acusación particular, ni el forzamiento de la acusación.

${ }^{49}$ Horvitz, M. I., Derecho Procesal Penal, Editorial Jurídica, Santiago, 2005, T. I, p. 587.

50 Maturana, C., y Montero, R., Derecho Procesal Penal Tomo II, Legal Publishing, Santiago, 2010, pp. 674-675. 
nuestro legislador". Y Novoa ${ }^{51}$ acepta la reapertura de la investigación así como una nueva formalización, solo limitando este segundo período, el que no podrá superar los dos años originales ${ }^{52}$.

Por nuestra parte, nada más apuntemos frente a quienes descartan absolutamente la reapertura del procedimiento, que al ordenar expresamente el legislador la reanudación del cómputo de la prescripción de la acción penal ante la comunicación de la decisión de no perseverar (Art. 248, inc. final, del CPP) no puede perseguir otro fin que el de autorizar que ella sea ejercida dentro del lapso restante, única manera de entender de alguna utilidad dicha mención. Además, el artículo $1^{\circ}$ inc. $2^{\circ}$ del CPP solo proscribe someter a una persona a un nuevo procedimiento penal si ella fue ya condenada, absuelta o sobreseída definitivamente por sentencia ejecutoriada, no así respecto de quien no se perseveró en el procedimiento, y por último, si no se admitiera reiniciar la investigación al MP, implicaría que la decisión de este organismo de no perseverar tiene un efecto procesal y sustantivo análogo al sobreseimiento definitivo, lo que requiere necesariamente un pronunciamiento jurisdiccional ${ }^{53}$. En otro caso, podría entenderse que tal decisión del MP al producir un efecto equivalente al de cosa juzgada supondría una atribución de poderes propiamente jurisdiccionales y por lo tanto inconstitucionales.

\section{Contenido de la acusación. Deber del Ministerio PÚBlico DE PRESENTAR UNA ACUSACión COMPLETA Y AJUSTAdA AL MÉRITO DE LA INVESTIGACIÓN}

Digamos en principio que, como regla, el deber de acusar si hay materia criminis incluye no sustraer de la acusación ningún elemento fáctico relevante para la determinación de la responsabilidad penal y cuantificación de la pena ${ }^{54}$, de ahí que el control del

${ }^{51}$ Novoa, J.P, “Análisis de la facultad del Ministerio Público de no perseverar en la investigación”, en Revista Procesal Penal, No 27, 2004, p. 29.

52 Aguilar, C., Manual de Derecho Procesal Penal Oral, Metropolitana, Santiago, 2004, T. I, pp. 416-417, estima que el MP puede abrir nuevamente la investigación y formalizar contra el mismo imputado y por los mismos hechos, en el evento que contare con elementos para proseguir la persecución criminal. La Fiscalía Nacional en Ministerio Público (2001) 37, considera que el proceso vuelve al estado de una investigación no formalizada para que el Fiscal continuare con la misma, si lo estimare procedente.

53 En SCS, Rol No 4.178-2005, de 16.11.2005, se resolvió que "la pretensión de que la decisión del Ministerio Público de no perseverar en un procedimiento equivalga a una sentencia absolutoria ejecutoriada, carece de todo fundamento legal (-) La decisión del Ministerio Público de no perseverar puede depender de una variedad de motivos, de entre los cuales solo sería uno la posible convicción de que el hecho investigado no ha ocurrido o que el imputado no ha participado en él". Esta solución de nuestro máximo Tribunal, deja entrever que la decisión de no perseverar puede albergar puros criterios de oportunidad, en circunstancias que, como aclara Martín, J., “Algunas manifestaciones de la aproximación entre el proceso penal y el proceso civil”, en Armenta, T., (coord.), La convergencia entre proceso civil y penal ¿Una dirección adecuada?, Marcial Pons, Madrid, 2013, p. 151, en relación con el procedimiento español, siendo la regla tradicional y general en el ordenamiento procesal-penal el principio de legalidad, para la aplicación de oportunidad es necesaria una norma expresa.

54 v. De la Oliva, A., Derecho Procesal Penal, Centro de Estudios Areces, Madrid, 1999, 4ª ed., p. 18. 
objeto del juicio referente a este aspecto se fundamente en el principio de obligatoriedad de la acción penal, por el que debe promoverse la acusación sobre el hecho y todas sus circunstancias relevantes para el derecho penal, sin que existan criterios en la ley que permitan al fiscal disponer del objeto del juicio ${ }^{55}$.

\section{Control jurisdiccional sobre la acusación incompleta}

Dicho lo anterior, distingamos entre la discrecional reducción de la acusación por el MP que excluye algún sujeto o hecho delictivo autónomo que haya sido comprendido en la formalización de la investigación, y aquella que recae sobre hechos o circunstancias accesorias al delito objeto de la formalización.

En lo que dice relación al primer grupo, si el Fiscal aparta discrecionalmente de su acusación algún hecho delictivo autónomo o algún hechor que había sido aludido en la formalización de la investigación, ello deberá encauzarse ya sea en una petición de sobreseimiento o en la comunicación de la decisión de no perseverar, frente a ello nos remitimos a lo dicho precedentemente acerca de los medios para afrontar tales peticiones o determinaciones del MP. Lo que no podría efectuar este es simplemente suprimir hechos punibles o personas considerados antes en la formalización, sin postular ningún término procesal a su respecto, ocasionando que permanezcan en una situación procesal indefinidamente incierta. Para evitar esto último es que el inc. $5^{\circ}$ del artículo 247 del CPP ha dispuesto que si así procediera el MP, el juez, de oficio o a petición de alguno de los intervinientes, deberá dictar sobreseimiento definitivo - parcial, en este caso- a su respecto.

Esta salida, si bien reviste de certidumbre la situación del imputado formalizado, por el contrario facilita también el desconocimiento del principio de obligatoriedad por el fiscal, pues el órgano jurisdiccional deberá decretar el sobreseimiento definitivo indicado aun cuando sea evidente que la omisión de la acusación respecto del hecho o sujeto excluido no obedezca a la insuficiencia de antecedentes reunidos, sino simplemente a una determinación discrecional del persecutor.

En cuanto a la segunda hipótesis, la deficiente regulación que hemos venido comentado deja bastante campo para que el MP, sin mutar esencialmente el hecho delictivo objeto de la formalización de la investigación, lo restrinja objetivamente, lo que le permitiría encuadrar el hecho ahora en una figura penal análoga atenuada, o atribuir formas de participación o de iter criminis menos intensas, o excluir circunstancias agravantes, todo ello, no obstante que los antecedentes reunidos durante la fase de pesquisas permitan prever razonablemente que los hechos, tal como originalmente fueron comunicados -en

55 Álvarez, A., "El control de la acusación. Pena y Estado", en Revista Latinoamericana de Política Criminal, Año 2, N 2, 1997, p. 28, concluyendo que "con base en el principio de obligatoriedad de la acción penal, el tribunal debe controlar el objeto del juicio incluido en la acusación y, eventualmente, podrá ingresar en el auto de apertura del juicio, circunstancias del hecho acusado no incluidas por el fiscal en su requerimiento. La facultad de ingreso es muy amplia, según el ordenamiento en análisis, por lo que el tribunal podría incorporar elementos fácticos que agraven el comportamiento, podrá modificar el grado de participación del acusado, el grado de desarrollo de la ejecución (tentado o consumado), cambiar el elemento subjetivo del injusto (dolo o culpa) e, incluso, variar el relato del hecho". 
la formalización-, habrían sido acreditados en el juicio oral. Ante este insatisfactorio ejercicio de la acción penal, nuestro ordenamiento no contempla una enmienda jurisdiccional ex officio, manteniéndose la lógica ya expuesta en cuanto a la imposibilidad de forzar al propio fiscal a extender su acusación a los puntos omitidos, restando nada más salvar esto mediante la intervención del acusador particular, a quien la ley faculta para "ampliar la acusación del fiscal, extendiéndola a hechos o a imputados distintos, siempre que hubieren sido objeto de la formalización de la investigación” (Art. 261 letra a) del CPP). Esta actuación del acusador particular habilitará al tribunal de juicio para extender su veredicto a los hechos o sujetos excluidos erróneamente por el MP de su acusación, y de ese modo subsanar el inacabado cumplimiento de su deber de ejercer la acción penal.

\section{BIBLIOGRAFÍA}

Aguilar, C., Manual de Derecho Procesal Penal Oral, Metropolitana, Santiago, 2004, T. I.

Aguilera, E., El principio de consenso: La conformidad en el proceso penal español, Cedecs, Barcelona, $1998,1^{a}$ ed.

Álvarez, A., "El control de la acusación. Pena y Estado", en Revista Latinoamericana de Política Criminal, Año 2, $\mathrm{N}^{\circ}$ 2, 1997.

Armenta, T. Criminalidad de bagatela y principio de oportunidad: Alemania y España, PPU, Barcelona, 1991.

Armenta, T., Estudios sobre el proceso penal, Rubinzal-Culzoni, Buenos Aires, 2008.

Armenta, T., Lecciones de derecho procesal penal. Marcial Pons, Madrid, 2010, 5a ed.

Armenta, T., Sistemas procesales penales. La justicia penal en Europa y América ¿ Un camino de ida y vuelta?, Marcial Pons, Madrid, Barcelona, Buenos Aires, 2012.

Armenta, T., "Algunas reflexiones en torno a la convergencia entre los procesos civil y penal y la deriva común hacia métodos extrajurisdiccionales”, en Armenta T. (Coord.), La convergencia entre proceso civil y penal ¿Una dirección adecuada?, Madrid, Marcial Pons, 2013.

Arocena, G. "De la acusación, del in dubio pro reo y de la garantía del debido proceso", en Cafferata, J. y Arocena, G., Temas de derecho procesal penal (Contemporáneos), Mediterránea, Córdoba, 2001, pp. 171-202.

Bettiol, G. Instituciones de derecho penal y procesal, trad. F. Gutiérrez-Alviz y Conradi, Bosch, Barcelona, 1977.

Burgos J. Modelo y propuestas para el proceso penal español, ePraxis. Sevilla, 2012.

Cafferata, J. Cuestiones actuales sobre el proceso penal, Editores del Puerto, Buenos Aires, 2000, $3^{\mathrm{a}}$ ed.

Castro, C. Resabios Inquisitivos en el Proceso Penal Chileno, Metropolitana, Santiago, 2010.

Cerda, R. y Hermosilla, F. El Código Procesal Penal. Comentarios, Concordancias y Jurisprudencia, Librotecnia, Santiago, 2006. $2^{\mathrm{a}}$ ed.

Clariá, J. Derecho Procesal Penal, Rubinzal-Culzoni, Buenos Aires, T. I.

Conde-Pumpido, C. "El principio de oportunidad reglada: su posible incorporación al sistema del proceso penal español", en AAVV. La Reforma del Proceso Penal. II Congreso de Derecho Procesal de Castilla y León, Ministerio de Justicia, Madrid, 1989, pp. 287-308.

De la Oliva, A. et al, Derecho Procesal Penal, Ed. Centro de Estudios Areces s.a., Madrid, $4^{a}$ ed.

Del Río, C. Los poderes de decisión del juez penal. Principio acusatorio y determinadas garantías procesales (el deber de correlación), Editorial Jurídica de Chile, Santiago, 2009. 
Díaz, J. Principios de aportación de parte y acusatorio: la imparcialidad del juez, Comares, Granada, 1996. Díez-Picazo, L.M., El poder de acusar, Ministerio Fiscal y Constitucionalismo, Ariel, Barcelona, 2000. Duce, M. y Riego, C. Proceso Penal. Editorial Jurídica de Chile, Santiago, 2009.

Fernández, M.Á. La nueva justicia penal frente a la Constitución, LexisNexis, Santiago, 2006. Ferrajoli, L. Derecho y razón. Teoría del garantismo penal. Trotta, Madrid, $5^{a}$ ed., 2001.

GARRIDO, M. "La instrucción penal. Investigación y formalización de la instrucción”, en AAVV. El Nuevo Proceso Penal Chileno, Universidad de Concepción, Facultad de Ciencias Jurídicas y Sociales, Depto. de Derecho Procesal, 2000, pp. 127-136.

Gimeno, V., Moreno, V., Cortés, V. Derecho Procesal Penal, Colex, Madrid, 1999, $3^{\mathrm{a}}$ ed.

Gómez, J-L. El proceso penal alemán. Introducción y normas básicas, Bosch, Barcelona, 1985.

Horvitz, M.I. y López, J. Derecho Procesal Penal Chileno, Editorial Jurídica de Chile, Santiago, 2005, T. I y II.

Maier, J. Derecho Procesal Penal. II. Parte General. Sujetos procesales, Editores del Puerto, Buenos Aires, 2003, $1^{\mathrm{a}}$ ed.

MARTín, J. El ministerio Fiscal como director de la investigación oficial en el proceso penal, Publicaciones del Real Colegio de España, Bolonia, 2005.

MARTín, J. "Algunas manifestaciones de la aproximación entre el proceso penal y el proceso civil", en Armenta T. (Coord.), La convergencia entre proceso civil y penal ¿Una dirección adecuada?, Marcial Pons, Madrid, 2013.

Maturana, C. "El Sobreseimiento", en Revista de Derecho Procesal, No 20, 2005, pp. 337-367.

Maturana, C. y Montero, R. Derecho Procesal Penal, Legal Publishing, Santiago, 2010, T. I y II.

Medina R., Morales, L. y Dorn, C. Manual de Derecho Procesal Penal, LexisNexis, Santiago, $2^{\mathrm{a}}$ ed., 2007.

Ministerio Público. Fiscalía Nacional. Reforma Procesal Penal: Instructivos Generales $N^{o s} 26$ a 50. Editorial Jurídica de Chile, Santiago, 2001.

Montero, J., Gómez, J, Montón, A., y Barona, S. Derecho Jurisdiccional. III. Proceso Penal, Bosch, Barcelona, 2013.

Montero, J., Ortells, M. y Gómez, J. Derecho Jurisdiccional. Parte General. I. Bosch, Barcelona, $1989,2^{a}$ ed.

Morosi, G. et al. "El sistema procesal penal italiano", en Hendler, E. (dir.) Sistemas Procesales Penales Comparados. Ad Hoc, Buenos Aires, 1999, pp. 133-208.

NovoA, J.P. "Análisis de la facultad del Ministerio Público de no perseverar en la investigación”, en Revista procesal penal, $\mathrm{N}^{\circ} 27,2004$, pp. 23-34.

NúÑEZ, J.C. Tratado del Proceso Penal y del Juicio Oral, Editorial Jurídica de Chile, Santiago, 2003.

Oliver, G. "¿Constituye un orden de prelación el listado de causas de sobreseimiento definitivo del artículo 250 del 'Código Procesal Penal'?”, en Revista de Derecho de la Pontificia Universidad Católica de Valparaíso, vol. XXXI, 2008, pp. 357-366.

Ortells, M. "Cuatro aproximaciones al nuevo proceso penal chileno desde la perspectiva del proceso penal en países de la Unión Europea”, en AAVV. El Nuevo Proceso Penal Chileno, Facultad de Ciencias Jurídicas y Sociales. Dpto. de Derecho Procesal. Universidad de Concepción, 2000, pp. 307-344.

Otero, M. "El Principio de oportunidad y salidas alternativas", en Revista de Derecho Procesal, $\mathrm{N}^{\circ} 20,2005$, pp. 295-336.

Piedrabuena, G. Introducción a la Reforma Procesal Penal, Fallos del Mes, Santiago, 2000.

Prada, J.R. "España”, en Maciá Gómez, R. Sistemas de Proceso Penal en Europa, Cedecs, Barcelona, 1998, pp. 91-124.

Roxin, C. Derecho Procesal Penal, trad. G. Córdoba y D. Pastor, Editores del Puerto, Buenos Aires, 2000. 
Ruiz, E. Estudios de Derecho procesal penal, Comares, Granada, 1995.

TAVolari, R. "De la prueba. Sistema probatorio. Medios de prueba. Valor probatorio", en AAVV. El Nuevo Proceso Penal Chileno. Universidad de Concepción, Facultad de Ciencias Jurídicas y Sociales, Depto. de Derecho Procesal, 2000, pp. 137-156.

TRILlo J. El fiscal en el nuevo proceso penal, Comares, Granada, 2008.

Valdés, R. "Libro II del Nuevo Código Procesal Penal", en AAVV. Apuntes de Derecho Procesal Penal. El Ministerio Público y el Proceso Penal Oral, LegalPublishing, 2010, $8^{\mathrm{a}}$ ed., pp. 165-218.

VArgas, J. E. "El Ministerio Público en el proceso penal, a la luz de la sensación de crisis en la justicia criminal”, en AAVV. El Ministerio Público para una nueva justicia criminal, Fundación Paz Ciudadana, Escuela de Derecho Universidad Diego Portales, Corporación de Promoción Universitaria, Santiago, 1994, pp. 189-201.

WeIgend, T. Prosecution: Comparative Aspects, en Encyclopedia of Crime E Justice, Macmillan Reference USA, New York, $2^{a}$ ed., vol. 3, 2002, pp. 1232-1242. 
